\title{
Kekuatan genggam tangan, skor Child Pugh, dan massa otot pada pasien dengan sirosis hati
}

Hand grip strength, Child Pugh score, and muscle mass in patients with liver cirrhosis

Amanda Trixie Hardigaloeh, Rino Alvani Gani, Irsan Hasan, Andri Sanityoso Sulaiman

Divisi Hepatobilier, Departemen Ilmu Penyakit Dalam Fakultas Kedokteran Universitas Indonesia / Rumah Sakit Umum Pusat Nasional Dr. Cipto Mangunkusumo

\begin{abstract}
Background: Malnutrition is independent factor related to morbidity, mortality and high cost of treatment in liver cirrhosis. Hand grip strength (HGS) is one of the method use for malnutrition detection and prognosis evaluation. The correlation of HGS with liver function (Child Pugh score) and muscle mass is controversial. These important evaluation is not yet avalaible in Indonesia. Objective: Aim of this study is to assess the role of HGS measurement in malnutrition and its correlation with liver function and muscle mass. Method: This is a cross-sectional study in liver cirrhosis patients at Hepatobiliary Clinic of Cipto Mangunkusumo Hospital from February to June 2015. Nutritional status was assessed by HGS. Muscle mass was obtained from bioimpedance. Data were analyzed using Spearman correlation test. Results: There were 115 patients liver cirrhosis at Hepatobiliary Clinic of Cipto Mangunkusumo Hospital, 112 patients who fit the inclusion criteria, consisted of 79 men and 33 women with mean age $54.15 \pm 10.55$ years, median Child Pugh score 6 (5-13) with median HGS 26 (11-50) $\mathrm{kgF}$, mean muscle mass $44.43 \pm 8.12 \mathrm{~kg}$. The median intake of energy 1334.82 (604.75-3023.7) kkal, median protein 45.87 (19-114.5) gram. Prevalence of malnutrition according HGS was $33 \%$. Hand grip strength is not correlated with Child Pugh score $(p=0.046 ; r=-0.19)$ however it is correlated with muscle mass $(p<0.00 ; r=0.70)$. Conclusion: There are 33\% malnutrition cases based on HGS in out patient liver cirrhosis. There is no correlation between HGS with Child Pugh score however HGS is correlated with muscle mass in liver cirrhosis.
\end{abstract}

KEY WORDS: Child Pugh score; hand grip strength; liver cirrhosis; muscle mass

\begin{abstract}
ABSTRAK
Latar belakang: Malnutrisi merupakan faktor independen yang berhubungan dengan morbiditas, mortalitas, dan tingginya biaya pengobatan sirosis hati. Kekuatan genggam tangan (KGT) merupakan suatu metode yang sering digunakan untuk mendeteksi malnutrisi dan menilai prognosis pasien. Hubungan KGT dengan skor Child Pugh dan massa otot masih dalam kontroversi. Indonesia sampai saat ini belum memiliki data tersebut. Tujuan: Studi ini bertujuan untuk menilai peran KGT dalam mendeteksi malnutrisi serta hubungannya dengan fungsi hati dan massa otot. Metode: Studi potong lintang pada pasien sirosis hati di Poliklinik Hepatobilier Rumah Sakit Cipto Mangunkusumo (RSCM) dari bulan Februari-Juni 2015. Status gizi dinilai berdasarkan KGT sedangkan massa otot diukur menggunakan bioimpedans. Analisis statistik menggunakan uji korelasi Spearman. Hasil: Terdapat 115 pasien yang kontrol di Poliklinik Hepatobilier RSCM, 112 pasien memenuhi kriteria penelitian, terdiri dari 79 laki-laki dan 33 perempuan. Rerata usia pasien 54,15 $\pm 10,55$ tahun; median skor Child Pugh sebesar 6 (5-13) dengan median KGT yaitu 26 (11-50) $\mathrm{kgF}$; dan rerata massa otot 44,43 $\pm 8,12 \mathrm{~kg}$. Median asupan energi 1.334,82 $(604,75-3023,7)$ kkal dan median asupan protein 45,87 $(9-114,5) \mathrm{g}$. Prevalensi malnutrisi berdasarkan KGT ditemukan sebanyak 33\%. Kekuatan genggam tangan tidak berkorelasi dengan skor CHILD PUGH ( $\mathrm{p}=0,046 ; \mathrm{r}=-0,19)$ tetapi berkorelasi dengan massa otot $(\mathrm{p}<0,001 ; \mathrm{r}=0,70)$. Simpulan: Terdapat $33 \%$ kasus malnutrisi berdasarkan KGT pada pasien sirosis rawat jalan. KGT tidak berkorelasi dengan skor Child Pugh tetapi berkorelasi dengan massa otot pasien sirosis hati.
\end{abstract}

KATA KUNCI: skor Child Pugh; kekuatan genggam tangan; sirosis hati; massa otot

Korespondensi: Rino Alvani Gani, Fakultas Kedokteran Universitas Indonesia / Rumah Sakit Umum Pusat Nasional Dr. Cipto Mangunkusumo, Jl. Diponegoro No. 71, Jakarta Pusat, DKI Jakarta, Indonesia, Telp (021) 3190024,e-mail: personaly@yahoo.com 


\section{PENDAHULUAN}

Sirosis hati merupakan stadium lanjut penyakit hati kronik yang ditandai dengan gagal hati dan hipertensi portal. Angka morbiditas dan mortalitas akibat sirosis hati semakin meningkat di negara maju dan merupakan suatu masalah kesehatan global $(1,2)$. Angka kesintasan 1 tahun sirosis hati Child Pugh A mencapai 100\%, Child Pugh B 80\% dan Child Pugh C 45\%. Saat penyakit hati sudah mencapai dekompensasi, maka tingkat mortalitas 5 tahun tanpa transplantasi mencapai $85 \%(2,3)$. Salah satu faktor prediktor prognosis independen terkait morbiditas, mortalitas serta tingginya biaya pengobatan pasien sirosis hati adalah status nutrisi (4-6). Malnutrisi sering dijumpai pada populasi sirosis hati (4). Semakin berat kondisi hati yang ditandai dengan peningkatan skor Child Pugh, maka prevalensi malnutrisi semakin tinggi. Pada suatu studi, didapatkan 95\% pasien sirosis hati Child Pugh C mengalami malnutrisi sedangkan Child Pugh B sebanyak 84\% dan Child Pugh A sebanyak 46 (7).

Malnutrisi energi protein pada pasien dengan gangguan fungsi hati memiliki hubungan langsung dengan progresivitas penyakit serta akan memperburuk derajat kerusakan hati $(5,8)$. Malnutrisi berkaitan dengan berbagai komplikasi antara lain dekompensasi hati, asites, ensefalopati, peritonitis, sindrom hepatorenal serta kualitas hidup yang buruk $(4,5,9)$. Hasil penelitian membuktikan bahwa malnutrisi meningkatkan mortalitas pasien sirosis hati yang menjalani rawat inap $(\mathrm{p}=0,001$; 95\%CI: 2,8-38,5) (10). Pasien malnutrisi akan mengalami komplikasi lebih banyak yaitu $65 \%$ vs $11 \%(\mathrm{p}=0,001)(5)$. Deteksi malnutrisi serta intervensi dini yang diberikan dapat mengurangi morbiditas dan mortalitas $(5,11,12)$.

Patogenesis malnutrisi ini bersifat multifaktor, yaitu kondisi hipermetabolisme, penurunan asupan kalori dan protein, malabsorbsi, gangguan metabolisme nutrisi serta peningkatan aktivitas $\beta$ adrenergik $(7,13)$. Pada umumnya, malnutrisi pada sirosis hati ditandai dengan hilangnya massa otot skeletal dan jaringan lemak. Sebuah studi mengatakan bahwa malnutrisi sirosis berawal dari ketidakseimbangan hidroelektrolitik di dalam sel otot (5). Upaya untuk mengkompensasi kondisi tersebut, maka terjadi deplesi jaringan dan sel otot sehingga $80 \%$ sumber protein viseral hilang dan terjadi perubahan komposisi tubuh (14).
Suatu tantangan dalam penilaian malnutrisi pada pasien sirosis hati adalah tidak adanya pemeriksaan baku emas sampai saat ini. Guideline ESPEN 2006 merekomendasikan penggunaan subjective global assessment (SGA), antropometri, serta kekuatan genggam tangan (KGT) untuk mengidentifikasi malnutrisi (15). Kekuatan genggam tangan merupakan pemeriksaan yang lebih sensitif untuk menilai status gizi dibandingkan metode lainnya. Kekuatan genggam tangan juga sangat praktis dilakukan pada praktik sehari-hari sehingga penilaian status gizi dapat dilakukan dengan mudah dan dini. Penelitian di Brasil dan Jepang menilai bahwa KGT dapat mendeteksi malnutrisi lebih banyak yaitu 69,3\% dibandingkan metode antropometri yang lain $(16,17)$.

Kekuatan genggam tangan juga merupakan salah satu modalitas untuk menggambarkan prognosis pasien sirosis hati. Hasil penelitian sebelumnya menemukan bahwa KGT lebih superior dibandingkan SGA sebagai prediktor komplikasi sirosis hati, yaitu sebanyak 65\% dibandingkan 35,7\% (5). Namun demikian, hubungan KGT dengan skor Child Pugh yang sering digunakan sebagai skor prognostik masih kontroversial. Studi yang dilakukan di India menemukan bahwa KGT berhubungan signifikan dengan skor Child Pugh. Penelitian tersebut melibatkan 352 pasien yang didominasi oleh pasien sirosis hati akibat alkohol (4). Sementara itu, penelitian di Brasil yang melibatkan 129 pasien dengan mayoritas pasien sirosis hati akibat virus hepatitis $\mathrm{C}$ menunjukkan bahwa KGT tidak berhubungan dengan skor Child Pugh (16).

Malnutrisi protein pada sirosis hati juga dikaitkan dengan hilangnya massa otot skeletal sehingga menyebabkan gangguan fungsi otot. Secara umum, sarkopenia merupakan penurunan massa otot yang dihubungkan dengan faktor usia. Namun, kondisi ini juga sering dijumpai pada pasien dengan gangguan fungsi (18). Sirosis hati akan membuat penurunan massa otot ini semakin berat karena terkait dengan tingkat keparahan penyakit dan kondisi portosystemic shunting (9). Pada populasi usia lanjut, prevalensi sarkopenia berkisar 4-27\% (19). Sementara pada sirosis hati, penelitian sebelumnya menemukan $40-68 \%$ pasien yang akan menjalani prosedur transplantasi hati sudah berada pada kondisi sarkopenia $(20,21)$. 
Pada awalnya, kondisi struktural otot seperti ukuran otot dikatakan sebagai penyebab primer dari penurunan kekuatan otot. Namun, akhir-akhir ini, ditemukan bahwa ukuran otot hanya memegang peranan kecil. Dari berbagai studi pada populasi usia lanjut, ditemukan hanya $35 \%$ studi yang menemukan adanya hubungan yang signifikan antara penurunan kekuatan otot dan penurunan massa otot. Pada populasi sirosis hati, belum ada yang menilai bagaimana hubungan antara penurunan massa dan kekuatan otot ini. Hingga saat ini, belum ada penelitian yang menilai KGT sebagai salah satu modalitas untuk menggambarkan prognosis di Indonesia serta korelasinya dengan massa otot pada sirosis hati. Penelitian ini bertujuan untuk menilai hubungan KGT terhadap massa otot dan skor prognosis Child Pugh pada pasien sirosis hati.

\section{BAHAN DAN METODE}

Penelitian ini menggunakan desain potong lintang dengan metode consecutive sampling. Penelitian dilakukan dengan menggunakan data sekunder pasien berusia lebih dari atau sama dengan 18 tahun yang berobat di poliklinik rawat jalan Hepatobilier Rumah Sakit Umum Pusat Nasional Dr. Cipto Mangunkusumo (RSCM) pada periode waktu Februari 2015 sampai Juni 2015. Ekstraksi data sekunder dari rekam medis akan dilakukan pada bulan Februari - Juni 2015. Populasi target pada penelitian ini adalah pasien berusia lebih dari atau sama dengan 18 tahun dengan sirosis hati Child Pugh A, B, C di Indonesia. Populasi terjangkau penelitian ini adalah pasien berusia lebih dari atau sama dengan 18 tahun dengan sirosis hati Child Pugh A, B, C di poliklinik rawat jalan Hepatobilier RSCM. Sampel penelitian merupakan bagian dari populasi terjangkau yang memenuhi kriteria inklusi dan tidak mempunyai kriteria eksklusi.

Besar sampel minimal yang diperlukan untuk mengukur status nutrisi dengan KGT dibutuhkan 90 subjek. Besar sampel minimal yang diperlukan untuk melihat hubungan KGT dengan Child Pugh diperlukan 85 subjek. Sementara itu, untuk melihat hubungan KGT dengan massa otot dibutuhkan 30 subjek. Pada penelitian ini digunakan sampel sebanyak minimal 90 subjek untuk melihat hubungan dan nilai seluruh variabel. Korelasi minimal yang digunakan berdasarkan minimal korelasi cukup yaitu 0,5 . Penelitian ini menggunakan derajat kepercayaan $95 \%$ dengan power penelitian $80 \%$. Kriteria inklusi penelitian adalah: 1) pasien rawat jalan berusia lebih dari atau sama dengan 18 tahun; 2) menderita sirosis hati; dan 3) bersedia ikut dalam penelitian. Kriteria eksklusi penelitian ini adalah: 1) pasien dengan gangguan anatomi dan fungsional tangan, contoh kelainan muskuloskeletal; 2) data di dalam rekam medis tidak lengkap; 3) tidak kooperatif; dan 4) pasien yang memiliki nilai presentase lemak tubuh kurang dari $3 \%$.

Sirosis hati ditegakkan dari biopsi hati atau pencitraan serta laboratorium. Skor Child Pugh dinilai melalui parameter klinis mengenai asites dan ensefalopati serta laboratorik kadar bilirubin serum, albumin, dan prothrombin time (PT). Kekuatan genggam tangan diukur menggunakan dinamometer dan massa otot diukur berdasarkan soft lean mass. Cara mengukur KGT yaitu pasien diposisikan duduk, bahu dalam keadaan adduksi, siku dalam posisi fleksi $90^{\circ}$, lengan bawah terfiksasi pada lengan kursi, dan pergelangan tangan dalam keadaan bebas. Pengukuran dilakukan dengan menggunakan dinamometer handgrip merk Jamar Hydraulic Hand Dynamometer pada kedua tangan, tiga pengukuran pada masing-masing tangan dengan periode selang seling selama 1 menit. Sebelumnya, pasien diberi contoh cara pemeriksaan KGT dan saat pemeriksaan dilakukan, pasien diberikan motivasi untuk menggenggam sekuat tenaga. Nilai yang diambil adalah nilai tertinggi.

Penilaian komposisi tubuh dilakukan menggunakan body composition analyzer Jawon GAIA 359. Pasien diminta untuk melepaskan semua benda logam yang menempel pada tubuh pasien, seperti jam tangan, cincin, dan lain-lain. Pasien juga diminta untuk melepaskan benda-benda yang dapat merancukan berat badan pasien, misalnya dompet, jaket, dll. Penilaian dilakukan saat pasien berada dalam posisi berdiri tegak lurus, menempelkan kedua kaki pada kedua elektroda yang diletakkan sesuai pijakan kaki. Kedua tangan memegang pegangan alat bioelectrical impedance analysis (BIA) dalam posisi tegak lurus ke arah bawah dan tidak menempel pada badan pasien. Selanjutnya pasien diukur berat badan terlebih dahulu dan diminta untuk menekan tombol yang terdapat pada pegangan alat BIA untuk 
beberapa saat sesuai instruksi mesin. Massa otot akan dilaporkan secara otomatis setelah pemeriksaan selesai dilakukan.

Korelasi KGT dengan skor Child Pugh dan massa otot diketahui dengan menggunakan uji korelasi Pearson atau uji Spearman karena skor Child Pugh yang digunakan adalah numerik. Penilaian korelasi ini juga akan dilakukan analisis subgroup terhadap variabel modifier. Penelitian ini telah disetujui oleh Komite Etik Penelitian Kesehatan Fakultas Kedokteran Universitas Indonesia - Rumah Sakit Cipto Mangunkusumo dengan nomor 70/UN2.F1/ETIK/2015. Penelitian ini diawali dengan memberikan informed consent pada pasien yang menjadi subjek penelitian dan dijaga kerahasiaan datanya.

\section{HASIL}

Sebanyak 115 pasien sirosis hati yang datang ke Poli Hepatobilier RSCM, 112 pasien yang dapat melanjutkan penelitian dan dianalisis. Karakteristik subjek penelitian dapat dilihat pada Tabel 1. Pasien yang ikut dalam penelitian ini memiliki rentang usia 27-80 tahun dengan rerata usia 54,15 $\pm 10,55$ tahun dan terbanyak berada pada rentang usia 50-59 tahun $(41,1 \%)$. Subjek sebagian besar $(70,5 \%)$ berjenis kelamin lakilaki dengan penyebab mayoritas adalah virus hepatitis (89,28\%). Rerata tinggi badan, berat badan serta indeks massa tubuh (IMT) adalah 162,4 $\pm 8,07 \mathrm{~cm} ; 61,97 \pm 11,12$ $\mathrm{kg}$; dan $23,47 \pm 3,76 \mathrm{~kg} / \mathrm{m}^{2}$. Pada penelitian ini, didapatkan rerata albumin subjek penelitian ini yaitu $3,73 \pm 0,63 \mathrm{~g} /$ $\mathrm{dL}$; median bilirubin 1,1 (0,1-5,01) mg/dL; serta median perbedaan PT sebesar 1,8 (0-8,30) detik. Mayoritas pasien tidak memiliki komplikasi asites $(60,7 \%)$ maupun ensefalopati $(82,1 \%)$.

Pencatatan asupan makan dilakukan dengan metode recall $2 \times 24$ jam dengan satuan bahan penukar, yang kemudian dilakukan konversi menjadi gram (g). Selanjutnya, penilaian asupan energi protein dinilai dengan menggunakan program nutrisurvey. Pada penelitian ini, diperoleh bahwa $68,8 \%$ pasien dan $64,3 \%$ pasien memiliki asupan energi dan protein di bawah kebutuhan sehari-hari (Tabel 2). Berdasarkan hasil anamnesis asupan makanan, ternyata keluhan anoreksia
Tabel 1. Karakteristik dasar subjek penelitian

\begin{tabular}{ll}
\hline Karakteristik (n = 112) & \multicolumn{1}{c}{$\mathbf{n}$} \\
\hline Umur (tahun, rerata \pm SB) & $54 \pm 10,5$ \\
Jenis kelamin (n,\%) & $79(70,5)$ \\
$\quad$ Laki-laki & $33(29,5)$ \\
$\quad$ Perempuan & $162,40 \pm 8,1$ \\
Tinggi badan (cm, rerata \pm SB) & $61,97 \pm 11,1$ \\
Berat badan $(\mathrm{kg}$, rerata \pm SB) & $23,47 \pm 3,8$ \\
IMT $\left(\mathrm{kg} / \mathrm{m}^{2}\right.$, rerata $\left.\pm \mathrm{SB}\right)$ & $1,1(0,1-5,01)$ \\
Bilirubin (mg/dL, median(rentang)) & $3,73 \pm 0,6$ \\
Albumin (g/dL, rerata $\pm \mathrm{SB})$ & $1,8(0-8,30)$ \\
PT (detik, median(rentang)) & \\
Asites (n,\%) & $58(60,7)$ \\
$\quad$ Tanpa asites & $38(33,9)$ \\
Asites ringan & $6(5,4)$ \\
$\quad$ Asites tidak terkontrol & \\
Ensefalopati (n, $\%)$ & $92(82,1)$ \\
Tanpa ensefalopati & $20(17,9)$ \\
Ensefalopati grade I-II & \\
Komorbiditas (n,\%) & $3(2,7)$ \\
TB paru & $20(17,9)$ \\
DM tipe 2 & $10(8,9)$ \\
Hipertensi & $6(5,4)$ \\
Keganasan & $1(0,9)$ \\
PPOK & $1(0,9)$ \\
CHF & $7(6,3)$ \\
CKD stadium 3-5 &
\end{tabular}

$\mathrm{IMT}=$ indeks massa tubuh $; \mathrm{PT}=$ prothrombin time $; \mathrm{TB}=$ tuberkulosis; $\mathrm{DM}=$ diabetes mellitus; $\mathrm{PPOK}=$ penyakit paru obstruktif kronis; $\mathrm{CHF}=$ congestive heart failure; $\mathrm{CKD}=$ chronic kidney disease; $\mathrm{SB}$ = simpang baku

Tabel 2. Asupan subjek penelitian

\begin{tabular}{lc}
\hline \multicolumn{1}{c}{ Asupan } & n = 112 \\
\hline $\begin{array}{l}\text { Energi (kkal) (median, rentang) } \\
\text { Protein (gram) } \\
\text { (median, rentang) }\end{array}$ & $4.334,82(604,8-3.023,7)$ \\
$\begin{array}{l}\text { Jumlah pasien kekurangan } \\
\text { asupan energi (n,\%) }\end{array}$ & $77(68,0-114,5)$ \\
$\begin{array}{l}\text { Jumlah pasien kekurangan } \\
\text { asupan protein (n,\%) }\end{array}$ & $72(64,3)$ \\
$\begin{array}{l}\text { Jumlah pasien anoreksia (n,\%) } \\
\text { Jumlah pasien mual/muntah } \\
(\mathrm{n}, \%)\end{array}$ & $12(10,7)$ \\
\hline
\end{tabular}

dan mual muntah tidak dominan terjadi pada pasien. Adanya hiperkatabolisme pada proses penyakit sirosis hati, mengakibatkan kebutuhan energi yang dibutuhkan lebih besar sehingga risiko untuk terjadinya malnutrisi lebih besar walaupun asupan makanan tidak terlalu banyak berkurang, khususnya pada pasien sirosis dengan stadium awal. 
Pada penelitian ini diperoleh sebanyak 53,6\% pasien adalah sirosis hati Child Pugh B (Tabel 3) dengan median skor Child Pugh adalah 6 (5-13). Rerata massa otot yang ditemukan pada penelitian ini adalah $44,43 \pm 8,12 \mathrm{~kg}$ dengan interval kepercayaan $95 \%$ $(42,91-45,96)$. Rerata massa otot laki-laki lebih berat dibandingkan perempuan. Median kekuatan genggam tangan subjek penelitian ini adalah 26 (11-50) $\mathrm{kgF}$. Laki-laki memiliki rerata KGT $(30,62 \pm 7,90 \mathrm{kgF})$ yang lebih tinggi dibandingkan perempuan $(19,27 \pm 4,02 \mathrm{kgF})$. Terdapat $33 \%$ subjek mengalami malnutrisi yang dinilai bedasarkan KGT. Laki-laki lebih banyak menderita malnutrisi dibandingkan perempuan, yaitu sebesar $39,2 \%$ vs $18,2 \%$ (Tabel 3).

Analisis bivariat dilakukan untuk mengetahui korelasi antara KGT dengan skor Child Pugh dan massa otot dengan tingkat kemaknaan $95 \%$. Semua variabel yang dianalisis yaitu KGT, skor Child Pugh, dan massa otot merupakan data numerik sehingga analisis bivariat yang digunakan adalah uji korelasi. Kekuatan korelasi ditunjukkan dengan koefisien korelasi (r). Berdasarkan uji normalitas, didapatkan KGT dan skor Child Pugh memiliki distribusi tidak normal sedangkan massa otot memiliki distibusi normal sehingga korelasi yang digunakan adalah uji Spearman. Pada penelitian ini ditemukan bahwa KGT tidak memiliki korelasi dengan skor prognosis Child Pugh $(\mathrm{p}<0,05 ; \mathrm{r}=$ $-0,19)$ (Gambar 1).

Penilaian KGT dipengaruhi oleh beberapa faktor seperti usia, jenis kelamin, komorbiditas, dan anemia. Selain itu, rerata subjek penelitian ditemukan pada usia yang cukup lanjut yaitu 54 tahun. Oleh karena itu, korelasi KGT dengan skor Child Pugh kemudian dilakukan subgrup yang analisis dengan faktor-faktor di atas (Tabel 4). Hasil analisis menunjukkan bahwa usia dan penyakit komorbid merupakan faktor modifier sedangkan jenis kelamin dan anemia merupakan faktor perancu. Faktor perancu tidak dapat dianalisis lebih lanjut karena syarat-syaratnya tidak terpenuhi. Pada grup usia, peneliti mengambil batasan usia 50 tahun. Hasil penelitian diperoleh bahwa pada usia lebih dari 50 tahun, didapatkan korelasi yang lebih kuat yaitu $r=-0,276 ; p=0,019$. Sementara pada grup penyakit komorbid, korelasi KGT dan Child Pugh pasien sirosis hati dengan komorbiditas didapatkan lebih kuat yaitu $\mathrm{r}=0,6 ; \mathrm{p}<0,001$.
Tabel 3. Skor Child Pugh, massa otot tubuh, dan kekuatan genggam tangan

\begin{tabular}{lc}
\hline Variabel & $\mathbf{n}=\mathbf{1 1 2}$ \\
\hline Skor Child Pugh (n,\%) & \\
Skor Child Pugh (median, rentang) & $6(5-13)$ \\
Child Pugh A & $44(39,3)$ \\
Child Pugh B & $60(53,6)$ \\
Child Pugh C & $8(7,1)$ \\
Massa otot (kg, rerata \pm SB) & $44,43 \pm 8,1$ \\
Laki-laki & $47,75 \pm 6,7$ \\
Perempuan & $36,49 \pm 5,2$ \\
Optimal (n,\%) & $33(29,5)$ \\
Kurang (n,\%) & $36(32,1)$ \\
Lebih (n,\%) & $43(38,4)$ \\
Kekuatan genggam tangan & \\
KGT (kgF, median (rentang)) & $26(11-50)$ \\
Laki-laki (rerata \pm SB) & $30,62 \pm 7,9$ \\
Perempuan (rerata \pm SB) & $19,27 \pm 4,0$ \\
\hline
\end{tabular}

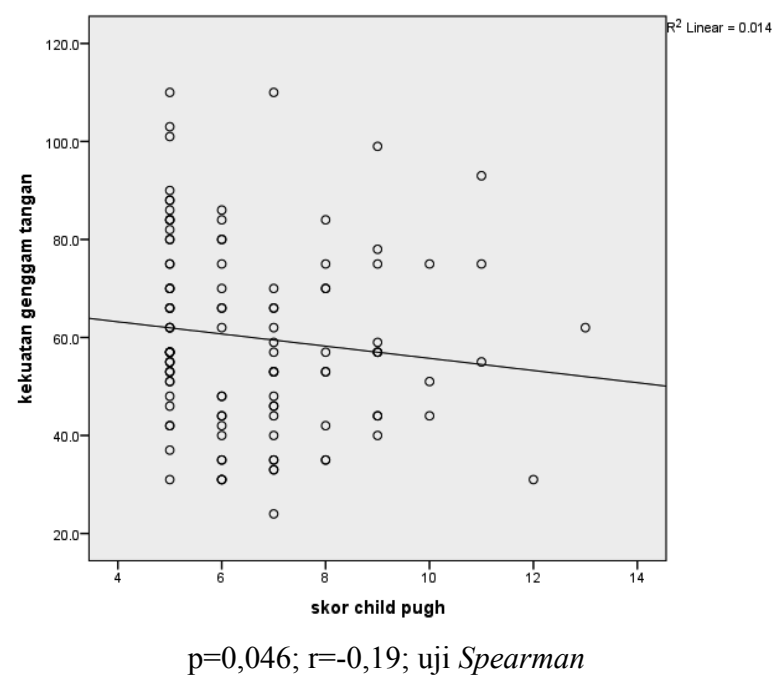

Gambar 1. Korelasi antara kekuatan genggam tangan dengan skor Child Pugh

Korelasi KGT dengan massa otot pada penelitian ini ditemukan cukup baik yaitu $\mathrm{r}=0,70 ; \mathrm{p}<0,05$ (Gambar 2). Pada korelasi KGT dan massa otot, analisis subgrup yang dilakukan menunjukkan bahwa jenis kelamin dan anemia merupakan faktor modifier sedangkan jenis kelamin dan komorbid merupakan faktor perancu. Faktor perancu tidak dapat dianalisis karena syarat-syaratnya tidak terpenuhi. Usia di bawah 50 tahun memiliki korelasi yang kuat yaitu $\mathrm{r}=0,77 ; \mathrm{p}<0,001$ sedangkan pada kelompok tidak anemia memiliki korelasi yang lebih kuat yaitu $\mathrm{r}=0,79 ; \mathrm{p}<0,001$ (Tabel 5). 
Tabel 4. Korelasi kekuatan genggam tangan dengan skor Child Pugh (analisis subgrup)

\begin{tabular}{lcc}
\hline Variabel & $\mathbf{r}$ & $\mathbf{p}$ \\
\hline Usia (tahun) & & \\
$\quad<50$ & $-0,155$ & 0,339 \\
$\geq 50$ & $-0,276$ & 0,019 \\
Jenis kelamin & & \\
$\quad$ Laki-laki & $-0,300$ & 0,007 \\
$\quad$ Perempuan & $-0,470$ & 0,006 \\
Komorbid & & \\
$\quad$ Komorbid (+) & $-0,600$ & $<0,001$ \\
$\quad$ Komorbid (-) & $-0,060$ & 0,618 \\
Hemoglobin & & \\
$\quad$ Anemia & $-0,125$ & 0,302 \\
$\quad$ Tidak anemia & $-0,167$ & 0,291 \\
\hline
\end{tabular}

Tabel 5. Korelasi kekuatan genggam tangan dengan massa otot (analisis subgrup)

\begin{tabular}{lccc}
\hline Variabel & Rerata & r & p \\
\hline Usia (tahun) & & & \\
$\quad<50$ & $29,87 \pm 9,7$ & 0,77 & $<0,001$ \\
$\quad \geq 50$ & $25,83 \pm 7,8$ & 0,68 & $<0,001$ \\
Jenis kelamin & & & \\
$\quad$ Laki-laki & $30,62 \pm 7,9$ & $-0,52$ & $<0,001$ \\
$\quad$ Perempuan & $19,27 \pm 4,0$ & $-0,59$ & $<0,001$ \\
Komorbid & & & \\
$\quad$ Komorbid (+) & $24,39 \pm 8,2$ & 0,70 & $<0,001$ \\
$\quad$ Komorbid (-) & $28,38 \pm 8,7$ & 0,70 & $<0,001$ \\
Hemoglobin & & & \\
$\quad$ Anemia & $25,93 \pm 7,8$ & 0,61 & $<0,001$ \\
$\quad$ Tidak anemia & $29,52 \pm 9,7$ & 0,79 & $<0,001$ \\
\hline
\end{tabular}

\section{BAHASAN}

\section{Prevalensi malnutrisi menggunakan kekuatan genggam tangan}

Prevalensi malnutrisi berdasarkan KGT yang ditemukan pada penelitian ini sebesar 33\%. Malnutrisi memang kerap ditemukan pada sirosis hati. Pada penelitian ini, walaupun mayoritas sirosis hati berada pada stadium Child Pugh A dan B, tetapi prevalensi malnutrisi cukup tinggi. Prevalensi malnutrisi pada penelitian ini sedikit berbeda dibandingkan ketiga penelitian sebelumnya yaitu sebesar $42 \%, 63 \%$, dan 69,3\%. Hal ini dapat terjadi karena perbedaan definisi operasional mengenai malnutrisi dan perbedaan karakteristik subjek penelitian $(4,5)$.

Pada penelitian ini, kondisi malnutrisi lebih banyak dijumpai pada laki-laki. Hal ini diduga karena

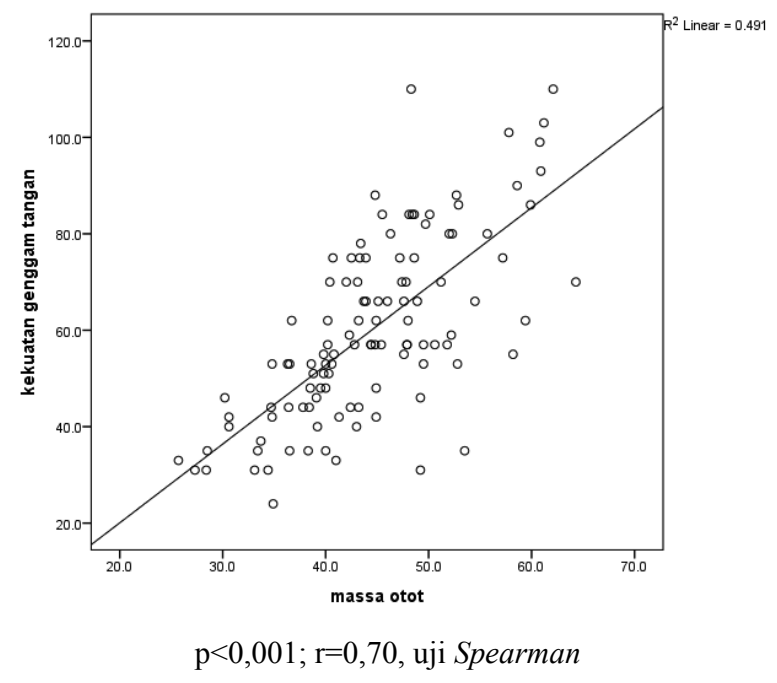

Gambar 2. Korelasi antara kekuatan genggam tangan dengan massa otot

laki-laki lebih banyak mengalami kehilangan jaringan akibat faktor hormonal. Defisiensi hormon testosteron dinilai mengakibatkan penurunan proses anabolisme. Berkurangnya hormon testosteron pada sirosis hati disebabkan penurunan produksi serta peningkatan transformasinya menjadi estrogen di hati. Hasil penelitian ini sesuai dengan penelitian sebelumnya yang menemukan bahwa deplesi protein lebih banyak ditemukan pada lakilaki. Deplesi konservasi protein pada laki-laki mencapai $20 \%$ dibandingkan pada perempuan yaitu sebesar $11 \%$ $(4,12)$.

\section{Korelasi kekuatan genggam tangan dengan skor Child Pugh}

Penelitian ini menemukan bahwa KGT tidak memiliki korelasi dengan skor Child Pugh ( $\mathrm{r}=0,19$; $\mathrm{p}<0,05)$. Secara stastistik, hasil penelitian ini cukup bermakna, tetapi korelasi secara klinis hubungan yang didapatkan sangat lemah atau tidak ada hubungan $(r<0,4)$ (22). Kekuatan korelasi ini tidak jauh berbeda dengan hasil penelitian sebelumnya yang menemukan KGT berhubungan signifikan dengan skor Child Pugh tetapi dengan korelasi yang sangat lemah $(r=0,3 ; p<0,05)(4)$. Pada penelitian ini, ditemukan bahwa KGT tidak dapat menggambarkan kondisi fungsi hati yang diwakili oleh skor Child Pugh. 
Hasil analisis subgrup yang dilakukan menunjukkan bahwa usia dan penyakit komorbid merupakan faktor modifier. Pada usia lebih dari 50 tahun, korelasi didapatkan lebih kuat $(r=-0,276)$ meskipun masih tergolong cukup lemah. Pada usia di atas 50 tahun, kekuatan otot mulai melemah. Namun demikian, melemahnya kekuatan genggam tangan pada usia lanjut ternyata tidak hanya dapat disebabkan oleh berkurangnya massa otot. Beberapa penelitian masih menunjukkan hasil yang kontroversi mengenai hubungan massa otot dan kekuatan genggam tangan. Faktor neurologi seperti menurunnya central nervous sistem drive, disfungsi saraf perifer, infiltrasi dari sel lemak, dan perubahan molecular juga memegang peranan penting yang menyebabkan berkurangnya kekuatan genggam tangan pada usia lanjut $(19,23)$.

Kekuatan genggam tangan pasien sirosis hati dengan penyakit komorbiditas memiliki korelasi yang lebih kuat $(r=-0,6 ; p<0,001)$. Faktor inflamasi nampaknya memegang peranan yang sangat penting. Penyakit kronik menyebabkan sitokin inflamasi seperti interleukin 6 (IL 6) dan Tumor Necrosis Factor £ (TNF) menjadi semakin meningkat. Hal ini dapat menyebabkan berkurangnya sel satelit yang menjaga homeostasis sel otot sehingga katabolisme otot semakin meningkat (19). Hal ini nampaknya mempengaruhi penilaian KGT bahwa semakin tinggi derajat inflamasi, maka KGT akan semakin rendah.

Jenis kelamin dan anemia ditemukan merupakan faktor perancu. Laki-laki merupakan salah satu faktor risiko terhadap prevalensi sirosis hati. Hal ini mungkin disebabkan oleh prevalensi penggunaan alkohol. Pada penyakit hati yang lanjut, juga seringkali ditemukan hipersplenisme yang menyebabkan pasien jatuh dalam kondisi anemia. Selain itu, komplikasi perdarahan sering dijumpai seiring semakin parahnya penyakit. Oleh karena itu, anemia juga dapat berperan sebagai faktor perancu

\section{Korelasi kekuatan genggam tangan dengan massa otot}

Penelitian ini menunjukkan bahwa pada pasien sirosis hati, fungsi otot berkorelasi cukup kuat dengan massa otot $(r=0,70 ; p<0,05)$. Hiperamonia diduga kuat sebagai penyebab dari sarkopenia pada sirosis hati. Hasil ini tidak jauh berbeda dengan hasil penelitian di New Zealand yang membuktikan bahwa deplesi protein secara signifikan mempengaruhi densitas tulang, kekuatan genggam tangan, dan respiratory muscle strength (24). Beberapa hasil penelitian juga membuktikan bahwa KGT bukan hanya dapat menilai kekuatan fungsional otot, tetapi juga dapat menilai secara umum struktural otot atau komposisi tubuh $(25,26)$.

Berdasarkan hasil analisis subgrup, ditemukan bahwa pada pasien sirosis hati yang berusia di bawah 50 tahun memiliki korelasi yang lebih kuat dalam menggambarkan hubungan KGT dan massa otot. Pada usia di atas 50 tahun, seperti telah dijelaskan di atas, termasuk pada pasien sirosis hati, faktor-faktor lain memiliki peranan dalam penurunan KGT ini. Keseimbangan massa otot dipengaruhi sintesis protein dan penghancurannya. Pada usia lanjut, ditemukan adanya pengurangan massa otot tetapi tidak ada perbedaan sintesis protein dibandingkan dengan kelompok dewasa muda. Faktor genetik seperti hormon pertumbuhan, miostatin, dan ekspresi sitokin juga berpengaruh terhadap perkembangan massa otot pada sebuah individu (27). Lebih lanjut, jenis kelamin juga berpengaruh pada kekuatan genggam tangan dan massa otot. Pada sirosis hati, laki-laki lebih rentan untuk mengalami deplesi protein sedangkan wanita lebih banyak mengalami deplesi lemak. Hasil penelitian sebelumnya menemukan bahwa $63 \%$ laki-laki mengalami deplesi protein dibandingkan perempuan sebanyak $28 \%$. Faktor homon seksual mungkin berperan dalam perbedaan pola kehilangan jaringan.

\section{SIMPULAN DAN SARAN}

Hasil penelitian ini menunjukkan terdapat 33\% kasus malnutrisi berdasarkan KGT pada pasien sirosis rawat jalan. Kekuatan genggam tangan tidak berkorelasi dengan skor Child Pugh. Namun, kekuatan genggam tangan berkorelasi positif dengan massa otot pasien sirosis hati. Selanjutnya, mengingat tingginya prevalensi malnutrisi pada pasien sirosis hati, diperlukan pelayanan terpadu pasien sirosis hati khususnya dalam skrining status gizi di poliklinik rawat jalan. Penelitian lanjutan dengan desain kohort prospektif mengenai kekuatan genggam tangan sangat disarankan untuk menilai 
prognosis pasien sirosis hati. Selain itu, juga diperlukan penelitian untuk mendapatkan nilai kekuatan genggam tangan pada populasi orang sehat di Indonesia karena belum adanya rentang normal tervalidasi dalam menilai kekuatan genggam tangan di Indonesia.

\section{Pernyataan konflik kepentingan}

Tidak ada konflik kepentingan pada penelitian ini.

\section{RUJUKAN}

1. Kim HJ, Lee HW. Important predictor of mortality in patients with end-stage liver disease. Clin Mol Hepatol 2013;19(2):105-15.

2. Tsochatzis EA, Bosch J, Burroughs AK. Liver cirrhosis. Lancet 2014;383:1749-61.

3. Schuppan D, Afdhal NH. Liver Cirrhosis. Lancet 2008;371:838-51.

4. Rauf A, Sharma P, Abdul M, Tyagi P, Bansalet N, Arora A, et al. Hand grip strength: an important tool for assessment of nutritional status in patients with liver cirrhosis. J Clin Exp Hepatol 2014;4:S47.

5. Alvares-da-Silva MR, Reverbel da Silveira T. Comparison between handgrip strength, subjective global assessment, and prognostic nutritional index in assessing malnutrition and predicting clinical outcome in cirrhotic outpatients. Nutrition 2005;21:113-7.

6. Teiusanu A, Andrei M, Arbanas T, Nicolaie T, Diculescu M. Nutritional status in cirrhotic patients. Maedica 2012;7:284-9.

7. Cheung K, Lee SS, Raman M. Prevalence and mechanisms of malnutrition in patients with advanced liver disease, and nutrition management strategies. Clin Gastroenterol Hepatol 2012;10(2):117-25.

8. Henkel AS, Buchman AL. Nutritional support in patients with chronic liver disease. Nat Clin Pract Gastroenterol Hepatol 2006;3(4):202-9.

9. Periyalwar P, Dasarathy S. Malnutrition in cirrhosis: contribution and consequences of sarcopenia on metabolic and clinical responses. Clin Liver Dis 2012;16(1):95131.

10. Merli M, Lucidi C, Giannelli V, Giusto M, Riggio O, Venditti M, et al. Cirrhotic patients are at risk for health care-associated bacterial infections. Clin Gastroenterol Hepatol 2010;8(11):979-85.

11. Tsiaousi ET, Hatzitolios AI, Trygonis SK, Savopoulos CG. Malnutrition in end stage liver disease: recommendations and nutritional support. J Gastroenterol Hepatol 2008;23(4):527-33.
12. Huisman EJ, Trip EJ, Siersema PD, van Hoek B, van Erpecum KJ. Protein energy malnutrition predicts complications in liver cirrhosis. Eur J Gastroenterol Hepatol 2011;23(11):982-9.

13. Merli M, Giusto M, Giannelli V, Lucidi C, Riggio O. Nutritional status and liver transplantation. J Clin Exp Hepatol 2011;1(3):190-8.

14. Eghtesad S, Poustchi H, Malekzadeh R. Malnutrition in liver cirrhosis:the influence of protein and sodium Middle East J Dig Dis 2013;5(2):65-75.

15. Plauth M, Cabre E, Riggio O, Assis-Camilo M, Pirlich M, ESPEN, et al. ESPEN guidelines on enteral nutrition: liver disease. Clin Nutr 2006;25(2):285-94.

16. Fernandes SA, Bassani L, Nunes FF, Aydos ME, Alves $\mathrm{AV}$, Marroni CA. Nutritional assessment in patients with cirrhosis. Arq Gastroenterol 2012;49(1):19-27.

17. Taniguchi E, Kawaguchi T, Itou M, Oriishi T, Ibi R, Sata $\mathrm{M}$, et al. Subjective global assessment is not sufficient to screen patients with defective hepatic metabolism. Nutrition 2011;27(3):282-6.

18. Montano-Loza AJ. Clinical relevance of sarcopenia in patients with cirrhosis. World J Gastroenterol 2014;20(25):8061-71.

19. Miljkovic N, Lim JY, Miljkovic I, Frontera WR. Aging of skeletal muscle fibers. Ann Rehabil Med 2015;39(2):15562.

20. Hanai T, Shiraki M, Nishimura K, Ohnishi S, Imai K, Moriwaki $\mathrm{H}$, et al. Sarcopenia impairs prognosis of patients with liver cirrhosis. Nutrition 2015;31(1):193-9.

21. Dasarathy S. Consilience in sarcopenia of cirrhosis. J Cachexia Sarcopenia Muscle 2012;3(4):225-37.

22. Alan RT PR, Sudigdo S, Muljono W, Partini P, Kemas F. Pemilihan uji hipotesis. In: Sudigdo Sastroasmoro SI, ed. Dasar-dasar metodologi penelitian klinis. Jakarta: Sagung Seto; 2010.

23. Clark BC, Manini TM. What is dynapenia?. Nutrition 2012;28:495-503.

24. Peng S, Plank LD, McCall JL, Gillanders LK, McIlroy K, Gane EJ. Body composition, muscle function, and energy expenditure in patients with liver cirrhosis: a comprehensive study. Am J Clin Nutr 2007;85(5):1257-66.

25. Montano-Loza AJ, Meza-Junco J, Prado CM, Lieffers $\mathrm{JR}$, Baracos VE, Sawyer MB, et al. Muscle wasting is associated with mortality in patients with cirrhosis. Clin Gastroenterol Hepatol 2012;10(2):166-73.

26. Norman K, Schutz T, Kemps M, Josef Lubke H, Lochs $\mathrm{H}$, Pirlich $\mathrm{M}$. The subjective global assessment reliably identifies malnutrition-related muscle dysfunction. Clin Nutr 2005;24(1):143-50.

27. Ribeiro SM, Kehayias JJ. Sarcopenia and the analysis of body composition. Adv Nutr 2014;5(3):260-7. 